\title{
COMPARISON OF LATERAL LINE SCALE COUNTS ON ARCTIC GRAYLING FROM YELLOWSTONE NATIONAL PARK AND MONTANA
}

\author{
William R, Gould \\ Cooperative Fishery Research Unit \\ Bozeman, Montana
}

\section{Int roduction}

Arctic grayling (Thymalitus arcticus) are presently absent from areas they formerly inhabited in Yellowstone National Park. A project has been begun to re-establish this species in areas of the Park within its former range. The purpose of this portion of the study was to examine the meristic characteristics of populations of Arctic grayling from Y.N.P. and Montana. The results of this work and those from the electrophoretic examination will provide information for the coliection of stocks to be used for the restoration of Arctic grayling in areas of Y.N.P.

\section{Methods}

Arctic grayling were collected from Y.N.P. and six locations in Montana. Specimens at MSU from seven sites (six different from above) also were examined. Numbers of scales in the lateral line series contained in the standard length were counted and compared statistically. McCart and Pepper (1971) found this count to be the most useful meristic tool for distinguishing grayling from different areas. Shreck and Behnke (1971) also have reported this feature to be useful for separating species and subspecies of Salmo, a closely related genus. In this study scales above the lateral lines and the number of rays in the pectoral fins were not useful in distinguishing populations.

\section{Results}

Two hundred twelve specimens from 13 locations were examined (Table 1). The average number of scales in the lateral line series was 87.89 with a standard deviation of 3.75. An analysis of variance indicated there was a significant difference $(P<.01)$ between the mean numbers of lateral line scales in the populations. The means were tested in the Compare program of the MSUTRAT series at Montana State University to determine which means were statistically different. The calculated $Q$ values showed the population from Red Rocks Creek drainage was significantly different from the populations in Hyalite Reservoir and Ennis Lake. There were no other statistical differences. 


\section{Discussion}

Lateral line scale counts did not show meaningful differences between the populations of Arctic grayling sampled. Seventy six (97\%) of the 78 mean comparisons made were not statistically significant. The two statistical differences between populations probably do not have biological significance. The population involved did not evolve in isolation.

Other considerations being equal, stock for introductions probably should be taken from populations with the greatest variability in lateral line scale counts. Variability in scale counts may indicate general genetic variation. Planting arctic grayling with high genetic variability should increase the chances of producing a successful introduction.

\section{Literature Cited}

McCart, P. and V. Pepper. 1971. Geographic variation in the lateral line scale counts of the Arctic grayling, ThymaZlus arcticus. J. Fish. Res. Bd. Canada 28(5):749-752.

Schreck, C. and R. Behnke. 1971. Trouts of the upper Kern River Basin, California, with reference to systematics and evolution of western North American Salmo. J. Fish. Res. Bd. Canada 28(7): 987-998. 
Table 1. Mean lateral line scale counts on populations of Arctic grayling from Yellowstone National Park and Moritana.

\begin{tabular}{|c|c|c|c|}
\hline Sampling Site & $\begin{array}{l}\text { Number of } \\
\text { Specimens }\end{array}$ & $\begin{array}{l}\text { Mean L.1.Scale } \\
\text { Count }\end{array}$ & $\begin{array}{l}\text { Standard } \\
\text { Deviation }\end{array}$ \\
\hline $\begin{array}{l}\text { Grebe and Wolf } \\
\text { Lakes, Y.N.P. }\end{array}$ & 41 & 87.66 & 3.99 \\
\hline $\begin{array}{l}\text { Mussigbrod Res., } \\
\text { Beaverhead Co., MT }\end{array}$ & 23 & 87.30 & 4.25 \\
\hline $\begin{array}{l}\text { Georgetown Lake, } \\
\text { Deer Lodge Co.,MT }\end{array}$ & 8 & 90.13 & 3.04 \\
\hline $\begin{array}{l}\text { Hyalite Res., } \\
\text { Gallatin Co., MT }\end{array}$ & 26 & 89.54 & 3.40 \\
\hline $\begin{array}{l}\text { Upper Big Hole River, } \\
\text { Beaverhead Co., MT }\end{array}$ & 20 & 87.05 & 3.09 \\
\hline $\begin{array}{l}\text { Emerald Lake, } \\
\text { Gallat in Co., MT }\end{array}$ & 19 & 88.63 & 2.03 \\
\hline $\begin{array}{l}\text { Deer Lake, } \\
\text { Gallatin Co., MT }\end{array}$ & 10 & 88.50 & 5.34 \\
\hline $\begin{array}{l}\text { Ennis Lake, } \\
\text { Madison Co., MT }\end{array}$ & 4 & 92.75 & 1.50 \\
\hline $\begin{array}{l}\text { Red Rock Cr. drainage, } \\
\text { Beaverhead Co., MT }\end{array}$ & 44 & 86.50 & 3.62 \\
\hline $\begin{array}{l}\text { Mud Lake, } \\
\text { Deer Lodge Co., MT }\end{array}$ & 4 & 88.50 & 2.89 \\
\hline $\begin{array}{l}\text { Rogers Lake, } \\
\text { Flathead Co., MT }\end{array}$ & 2 & 90.50 & 6.36 \\
\hline $\begin{array}{l}\text { Elk Lake, } \\
\text { Beaverhead Co., MT }\end{array}$ & 2 & 90.50 & 0.71 \\
\hline $\begin{array}{l}\text { Long Cr., } \\
\text { Beaverhead Co., MT }\end{array}$ & 9 & 86.44 & 2.55 \\
\hline
\end{tabular}

